\title{
Statistical exploration of gaseous elemental mercury (GEM) measured at Cape Point from 2007 to 2011
}

\author{
A. D. Venter ${ }^{1}$, J. P. Beukes ${ }^{1}$, P. G. van Zyl ${ }^{1}$, E.-G. Brunke ${ }^{2}$, C. Labuschagne ${ }^{2}$, F. Slemr ${ }^{3}$, R. Ebinghaus ${ }^{4}$, and H. Kock ${ }^{4}$ \\ ${ }^{1}$ Unit for Environmental Sciences and Management, North-West University, Potchefstroom, South Africa \\ ${ }^{2}$ South African Weather Service, P.O. Box 320, Stellenbosch 7599, South Africa \\ ${ }^{3}$ Max-Planck-Institut für Chemie, Hahn-Meitner-Weg 1, 55128 Mainz, Germany \\ ${ }^{4}$ Helmholtz-Zentrum Geesthacht, Institute of Coastal Research, Max-Planck-Strasse, 21502 Geesthacht, Germany
}

Correspondence to: P. G. van Zyl (pieter.vanzyl@nwu.ac.za)

Received: 8 December 2014 - Published in Atmos. Chem. Phys. Discuss.: 12 February 2015

Revised: 12 June 2015 - Accepted: 26 August 2015 - Published: 16 September 2015

\begin{abstract}
The authors evaluated continuous high-resolution gaseous elemental mercury (GEM) data from the Cape Point Global Atmosphere Watch (CPT GAW) station with different statistical analysis techniques. GEM data were evaluated by cluster analysis and the results indicated that two clusters, separated at $0.904 \mathrm{ng} \mathrm{m}^{-3}$, existed. The air mass history for the two-cluster solution was investigated by means of back-trajectory analysis. The air mass back-trajectory net result showed lower GEM concentrations originating from the sparsely populated semi-arid interior of South Africa and the marine environment, whereas higher GEM concentrations originated predominately along the coast of South Africa that most likely coincide with trade routes and industrial activities in urban areas along the coast. Considering the net result from the air mass back-trajectories, it is evident that not all low GEM concentrations are from marine origin, and similarly, not all high GEM concentrations have a terrestrial origin. Equations were developed by means of multi-linear regression (MLR) analysis that allowed for the estimation and/or prediction of atmospheric GEM concentrations from other atmospheric parameters measured at the CPT GAW station. These equations also provided some insight into the relation and interaction of GEM with other atmospheric parameters. Both measured and MLR calculated data confirm a decline in GEM concentrations at CPT GAW over the period evaluated.
\end{abstract}

\section{Introduction}

Mercury $(\mathrm{Hg})$ is a volatile metal emitted into the atmosphere, naturally or through anthropogenic activities, such as the combustion and processing of fossil fuels (Pirrone et al., 2010). It can be transported over large distances in the atmosphere due to its low reactivity and solubility. The removal of $\mathrm{Hg}$ from the atmosphere is facilitated mainly through wet deposition. This occurs when $\mathrm{Hg}$ is oxidised to less volatile and more soluble compounds (Lin et al., 2006). The deposited aqueous $\mathrm{Hg}$ compounds can then be converted into methylated $\mathrm{Hg}$, which is a potent toxin for humans and animals. Methylated $\mathrm{Hg}$ bio-accumulates in the aquatic food chain and may lead to the build-up of high concentrations in predatory fish that can pose serious health risks to people and animals that depend on a fish diet (Mergler et al., 2007). These negative environmental impacts of $\mathrm{Hg}$ have led to an increase in atmospheric $\mathrm{Hg}$ research (Lindberg et al., 2007).

Current emission inventories and models indicate that anthropogenic emissions are the largest source of atmospheric $\mathrm{Hg}\left(2880 \mathrm{t} \mathrm{yr}^{-1}\right)$, followed by marine $\left(2680 \mathrm{t} \mathrm{yr}^{-1}\right)$ and terrestrial $\left(1850 \mathrm{t} \mathrm{yr}^{-1}\right)$ sources (Mason, 2009; Pirrone et al., 2010). Industrial coal combustion processes, which include electricity generation, petrochemical plants and gasification processes, are considered to be the major anthropogenic sources of atmospheric Hg (Laudal et al., 2000; Wagner, 2001). It is estimated that coal combustion accounts for approximately a third of anthropogenic $\mathrm{Hg}$ emissions in the United States of America (USA) (Laudal et al., 2000). Other main sources of anthropogenic Hg emissions include 
non-ferrous metal production, gold refining, cement production and other combustion sources. The United States Environmental Protection Agency (US-EPA) introduced the Clean Air Mercury Rule in March 2005 enforcing the capping of mercury emissions from new and existing coal-fired power plants. The USA and European Union (EU) were among the first to regulate $\mathrm{Hg}$ pollution, and it is widely expected that this could significantly influence the way in which South Africa adopts Hg control legislation. In 2013, the Minamata Treaty was signed by South Africa and 98 other countries to protect human health and the environment from anthropogenic emissions and releases of elemental $\mathrm{Hg}$ and $\mathrm{Hg}$ compounds. It is expected that the Minamata Treaty will have far-reaching implications for South Africa, since it is globally considered to be the 6th largest emitter of mercury, emitting $\sim 50 \mathrm{t} \mathrm{yr}^{-1}$ due to the reliance on fossil fuels (Scott and Mdluli, 2012).

The global uncertainty associated with anthropogenic $\mathrm{Hg}$ emissions is considered to be $\pm 30 \%$, while the uncertainties associated with emissions from oceans and terrestrial surfaces are $\pm 50 \%$ (Lin et al., 2006; Lindberg et al., 2007). Long-term monitoring of $\mathrm{Hg}$ is important to reduce these uncertainties associated with $\mathrm{Hg}$ emissions from different sources, as well as to provide important information relating to the oxidation mechanism of atmospheric $\mathrm{Hg}$ (Slemr et al., 2008, 2013). Although atmospheric Hg is monitored extensively in the Northern Hemisphere, few studies have been published in peer-reviewed literature for the Southern Hemisphere (Ebinghaus et al., 2002; Slemr et al., 2011, 2015; Angot et al., 2014). The German Antarctic research station measured total gaseous Hg (TGM) from January 2000 to January 2001 (Ebinghaus et al., 2002). Gaseous elemental Hg (GEM) measurements have been conducted at the Cape Point Global Atmosphere Watch (CPT GAW) atmospheric monitoring station in South Africa since 1995 and have yielded several publications on long-term trends, depletion events, seasonal cycles and flux rates (Baker et al., 2002; Slemr et al., 2008; Brunke et al., 2010a, b). From 1995 until 2004, approximately 200 3-hour GEM samples have been collected each year with a manual double amalgamation technique (Slemr et al., 2008) at the CPT GAW station, while continuous high-resolution $\mathrm{Hg}$ measurements commenced in 2007.

In this paper, a combination of different statistical techniques was applied to continuous high-resolution $\mathrm{Hg}$ data collected between March 2007 and December 2011, as well as back-trajectory analyses that were performed in order to provide greater insight into the source regions of GEM at the CPT GAW station. This approach is different from previous studies of GEM measured at the CPT GAW station, where measurements of the most stable radon isotope $\left({ }^{222} \mathrm{Rn}\right)$ were used to determine the origin of air masses, i.e. maritime or continental (Brunke et al., 2004; Slemr et al., 2013). The relationship between GEM and other atmospheric parameters measured at the CPT GAW station was also determined sta-

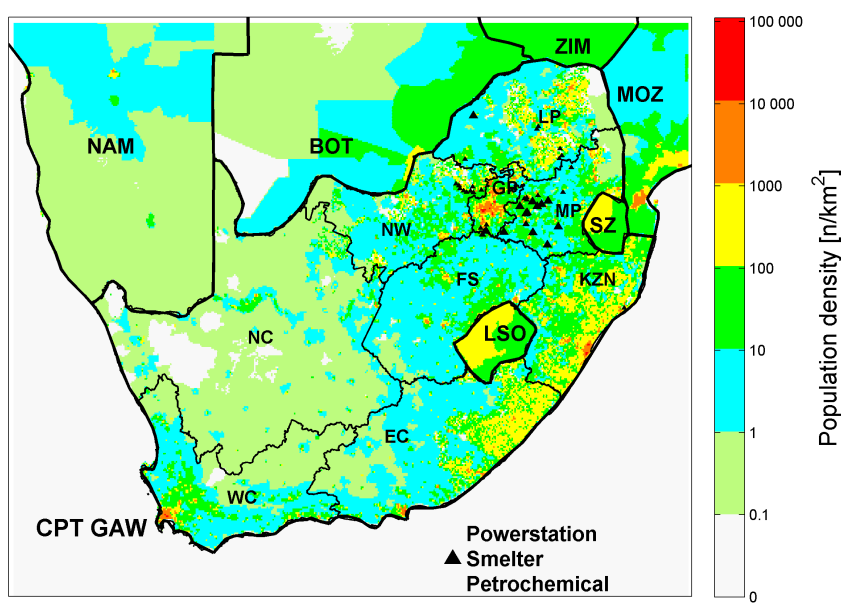

Figure 1. Position of CPT GAW within a regional context. The population density (people per $\mathrm{km}^{2}$ ) provides an indication of the possible location of anthropogenic pollution sources, while the location of large anthropogenic point sources (e.g. coal-fired power stations, metallurgical smelters and petrochemical plants, adapted from Venter et al., 2012 and Lourens et al., 2011, 2012) is also indicated. $\mathrm{NAM}=$ Namibia, BOT $=$ Botswana, ZIM = Zimbabwe, MOZ = Mozambique, SZ = Swaziland, LSO = Lesotho, $\mathrm{WC}=$ Western Cape, $\mathrm{EC}=$ Eastern Cape, $\mathrm{NC}=$ Northern Cape, $\mathrm{NW}=$ North West, FS = Free State, KZN = KwaZulu-Natal, GP = Gauteng, $\mathrm{MP}=$ Mpumalanga and LP $=$ Limpopo.

tistically in order to establish whether GEM levels could be estimated or predicted from these parameters.

\section{Experimental}

\subsection{Site description}

The CPT GAW station $\left(34^{\circ} 21^{\prime} \mathrm{S}, 18^{\circ} 29^{\prime} \mathrm{E}\right)$ is located in a nature reserve approximately $60 \mathrm{~km}$ south of Cape Town at the southernmost tip of the Cape Peninsula on the top of a coastal cliff at $230 \mathrm{~m}$ above sea level. Its location within a regional context is indicated in Fig. 1. The site experiences moderate temperatures with dry summers during which occasional biomass burning events in the surrounding area occur and increased precipitation during the winter (Slemr et al., 2013). Figure 1 is a composite map indicating population density and major point sources (Lourens et al., 2011, 2012; Venter et al., 2012) in South Africa. Population density data were obtained from the Socioeconomic Data and Applications Center (SEDAC) - a data centre in the Earth Observing System Data and Information System (EOSDIS) of the National Aeronautics and Space Administration (NASA). As is evident from Fig. 1, the industrial hub of South Africa that is concentrated around the Johannesburg-Pretoria megacity conurbation (in the Gauteng Province (GP)) and a relatively high density of large point sources (e.g. coalfired power plant, petrochemical operations, metallurgical 
smelters) located in parts of the Mpumalanga (MP), North West (NW) and Free State (FS) provinces that border on GP, are somewhat remote from the CPT GAW station. The nearest large anthropogenic point or area sources that could impact the CPT GAW station directly include the Cape Town metropolitan area, industries associated with the conurbation and an iron smelter on the west coast at Saldanha.

\subsection{Sampling}

Continuous $\mathrm{Hg}$ measurements were conducted with a Tekran 2537A vapour-phase mercury analyzer (Tekran Inc., Toronto, Canada) with a 15-min time resolution. A description of the instrument, as well as its calibration and maintenance were presented by Slemr et al. $(2008,2013)$. The analyser is capable of measuring low $\mathrm{Hg}$ concentrations typically measured at background locations (Ebinghaus et al., 1999), with a TGM detection limit of $\sim 0.05 \mathrm{ng} \mathrm{m}^{-3}$. Under the prevailing atmospheric conditions at the CPT GAW station, and due to the presence of hygroscopic sea salt aerosols, it can be assumed that the reactive gaseous mercury (RGM) will be adsorbed by the inlet tubing and the aerosol filter allowing for the exclusive measurement of atmospheric GEM (Brunke et al., 2010b). The $15 \mathrm{~min}$ GEM data have been converted to $30 \mathrm{~min}$ averages in order to correlate the results with other trace gas and meteorological measurements at CPT GAW. As described by Brunke et al. (2004), the ${ }^{222} \mathrm{Rn}$ detector was designed by the Australian Nuclear Scientific, and Technology Organisation (ANSTO) and was partially constructed locally. Trace gas measurements are drawn from the top of a $30 \mathrm{~m}$ high mast located on the instrument deck of the laboratory. Several trace gases (carbon monoxide $(\mathrm{CO})$; carbon dioxide $\left(\mathrm{CO}_{2}\right)$; methane $\left(\mathrm{CH}_{4}\right)$; ozone $\left(\mathrm{O}_{3}\right)$; nitrogen dioxide $\left.\left(\mathrm{NO}_{2}\right)\right)$, and halocarbons are measured at CPT GAW on a continuous basis. Of these, $\mathrm{CO}, \mathrm{CO}_{2}, \mathrm{CH}_{4}$ and $\mathrm{O}_{3}$ are used in this paper. Detailed instrumental descriptions of these instruments and meteorological parameters measured can be found in previous publications (Brunke et al., 1990, 2004, 2010).

\subsection{Statistical analysis}

In contrast to previously published atmospheric measurements of the CPT GAW station, the data set used in this paper was not de-trended (Brunke et al., 2004). The complete data set (March 2007 to December 2011) was evaluated statistically in order to determine the influence and interaction of GEM and other atmospheric species on a temporal and spatial basis. The statistical techniques applied are subsequently discussed.

During cluster analysis, GEM data were processed in MATLAB ${ }^{\circledR}$ by making use of the $k$-means function from the clustering toolbox. $K$-means clustering is an iterative partitioning method that uses squared Euclidean distances to partition a data matrix into $k$ clusters. The centroid of each cluster is the mean of the points in that cluster. $K$-means uses a two-phase iterative algorithm to minimise the sum of pointto-centroid distances, summed over all $k$ clusters. All GEM data considered, i.e. 41499 measurements, were subjected to five consecutive iterations using cluster analysis. Silhouette numbers obtained from the clustering were further considered to quantify the separation of the clusters. Silhouette numbers are a measure of how close individual points in a specific cluster are to points in the neighbouring clusters. The silhouette numbers range from +1 , indicating points that are very distant from neighbouring clusters, through 0 , indicating points that are not distinctly in one cluster or another, to -1 , indicating points that are probably assigned to the wrong cluster.

Multi-linear regression (MLR) analysis models the relationship between two or more explanatory independent variables and a dependant variable by fitting a linear equation to the observed data. The MLR equation obtained can be utilised to calculate values for the dependent variable. In this study, GEM values were considered the dependent variable, while 27 other ancillary data parameters (such as gaseous species concentrations and meteorological data) were considered the explanatory independent variables. MLR was used to determine the optimum combination of independent variables to derive an equation that could be used to predict GEM concentrations, while root mean square error (RMSE) was used to compare the calculated values with the measured values.

\subsection{Back-trajectory analysis}

The origin of air masses arriving at CPT GAW was determined by making use of NCEP (National Centers for Environmental Prediction) GDAS (Global Data Assimilation System) data obtained from NOAA ARL (Air Resources Laboratory of National Oceanic and Atmospheric Administration, ftp://arlftp.arlhq.noaa.gov/pub/archives/gdas1/). Individual 8-day back trajectories with hourly arrival times at an arrival height of $100 \mathrm{~m}$ (above ground level) were calculated with the Hybrid Single Particle Lagrangian Integrated Trajectory Model (HYSPLIT) 4.820. An arrival height of $100 \mathrm{~m}$ was chosen since the orography in HYSPLIT is not very well defined, and therefore lower arrival heights could result in increased error margins on individual trajectory calculations. Considering the above, 24 back trajectories for each day were obtained for the entire sampling period. Individual back trajectories generated in HYSPLIT (24/day $\times$ 365 days $\times \sim 5$ years) were superimposed and further analysed in MATLAB ${ }^{\circledR}$ to form overlay back trajectory maps. In these overlay back trajectory maps, a colour code indicates the percentage of trajectories passing over $0.2^{\circ} \times 0.2^{\circ}$ grid cells, with red being the highest percentage. Therefore, such images indicate the main areas over which air masses arriving at CPT GAW had passed. Similar overlay back trajectory analyses have previously been used in other non-GEM 


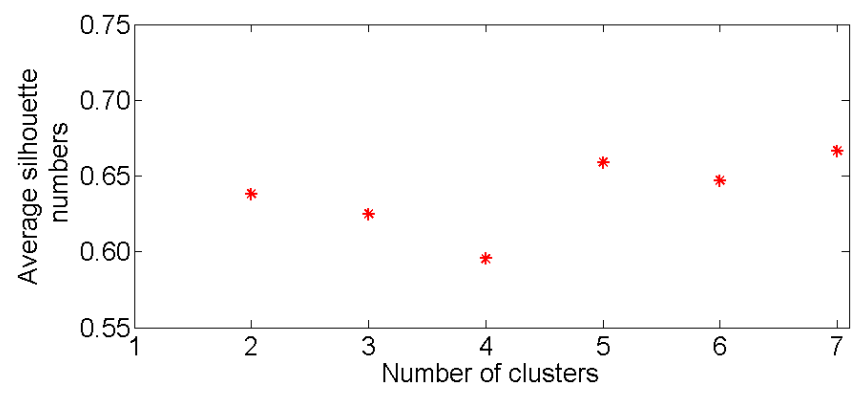

Figure 2. Average silhouette numbers for the various cluster solutions. An increase in silhouette numbers indicates that individual sub-clusters are better separated.

Table 1. The percentage GEM data distribution observed for each cluster solution.

\begin{tabular}{rrrrrrrr}
\hline \multicolumn{10}{c}{ \% GEM distribution in each cluster } \\
\hline $\begin{array}{r}\text { Cluster } \\
\text { solutions }\end{array}$ & 1 & 2 & 3 & 4 & 5 & 6 & 7 \\
\hline 2 & 36.79 & 49.07 & & & & & \\
3 & 3.35 & 41.34 & 41.18 & & & & \\
4 & 1.78 & 28.54 & 16.02 & 39.52 & & & \\
5 & 18.37 & 0.05 & 27.27 & 38.47 & 1.70 & & \\
6 & 11.43 & 31.36 & 1.36 & 27.29 & 0.05 & 14.37 & \\
7 & 1.51 & 1.23 & 29.62 & 11.34 & 16.76 & 25.38 & 0.02 \\
\hline
\end{tabular}

related atmospheric studies, e.g. Venter et al. (2012), Lourens et al. (2011) and Vakkari et al. (2013).

\section{Results}

\subsection{Cluster analysis}

Cluster analysis of GEM data was performed to statistically determine the optimal number of clusters that the data could be divided into. The cluster analysis results were assessed by calculating the average silhouette numbers of each cluster solution. Figure 2 shows the average silhouette numbers for the various cluster solutions. According to these results, dividing the GEM data into two clusters yielded an average silhouette number of 0.638 , while three or four cluster divisions yielded lower average silhouette numbers. The division of the GEM data into five to ten clusters yielded higher average silhouette numbers, which indicate better separation between clusters. In Table 1, the percentage GEM data distribution (columns) of each cluster solution (rows) is presented, and indicates that cluster solutions containing more than four clusters did not contain statistically significant amounts of GEM data in each cluster, e.g. the five-, six- and seven-cluster solutions all had clusters with $\leq 0.05 \%$ of the data. Therefore, the two-cluster solution was chosen as the optimal representation for this study. The GEM data distribution in the two clusters for the entire sampling period is presented in

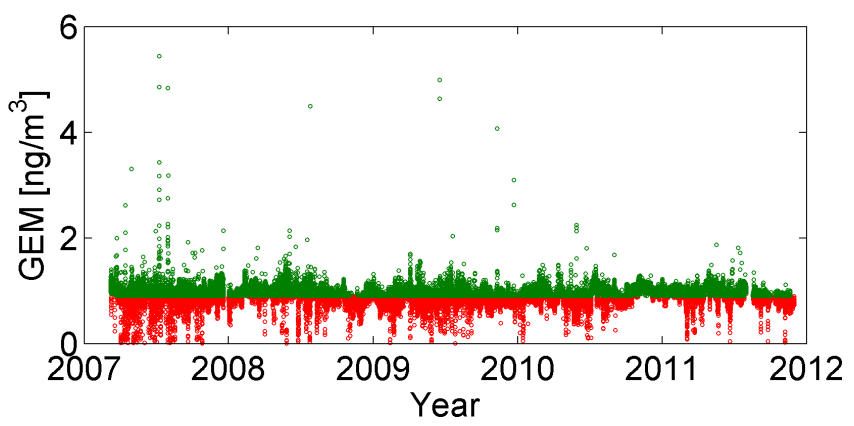

Figure 3. A scatter plot of GEM concentrations over the entire sampling period indicating the two main clusters. According to the clustering applied, division between the two clusters was at a GEM concentration of $0.904 \mathrm{ng} \mathrm{m}^{-3}$.

Fig. 3. According to the clustering approach applied, separation between the two clusters was at a GEM concentration of $0.904 \mathrm{ng} \mathrm{m}^{-3}$. Figure 3 also indicates a small number of data points with GEM concentrations $>\sim 2 \mathrm{ng} \mathrm{m}^{-3}$ that could be investigated as possible plume events, or special case studies. However, these possible higher concentration case studies were not considered in this paper, but may be an important topic to consider in future studies.

\subsection{Source region analysis}

In order to identify possible sources and/or source regions, the two clusters identified were further investigated by means of associating the arrival times of calculated back trajectories with the GEM data in the two different clusters. This was performed by correlating the GEM concentrations measured during the half hour before and the half hour after the hourly arrival time of the calculated back trajectory. Therefore, all the calculated back trajectories could be divided as being associated with one of the two GEM data clusters. The normalised (to $100 \%$ ) overlay back trajectory analysis map associated with GEM data cluster one, i.e. GEM concentration $>0.904 \mathrm{ng} \mathrm{m}^{-3}$, is presented in Fig. 4a, while the overlay back trajectory analysis associated with cluster two, i.e. GEM concentration $<0.904 \mathrm{ng} \mathrm{m}^{-3}$, is shown in Fig. 4 b. From both of these overlay back trajectory maps, it is evident that CPT GAW is mainly influenced by air masses from the south west that had passed mainly over the marine background. It also seems as if the air masses associated with GEM concentrations $<0.904 \mathrm{ng} \mathrm{m}^{-3}$ (cluster two, Fig. 4b) have a slightly larger fetch region over the ocean than the air masses associated with GEM concentrations $>0.904 \mathrm{ng} \mathrm{m}^{-3}$ (cluster one, Fig. 4a). However, significant differences between these two overlay trajectory maps, which could indicate possible differences in sources/source regions for the two GEM clusters, are not that evident. Therefore, a third overlay trajectory map (Fig. 4c) was drawn, which represents the difference between the two individual maps, i.e. subtracting the percentage of trajectories passing 
over each correlating $0.2^{\circ} \times 0.2^{\circ}$ grid cell in Fig. $4 \mathrm{~b}$ from the percentage of trajectories passing over each $0.2^{\circ} \times 0.2^{\circ}$ grid cell in Fig. 4a. In Fig. 4c, positive values (red) correspond with areas over which cluster one's $\left(>0.904 \mathrm{ng} \mathrm{m}^{-3}\right)$ air masses dominated, whereas negative values (dark blue) indicate areas over which air mass movement of cluster two $\left(<0.904 \mathrm{ng} \mathrm{m}^{-3}\right)$ were dominant. From this map (Fig. 4c), two observations can be made. Firstly, oceanic regions along both the east- and west coast around CPT GAW correspond with air masses mostly related to cluster one (higher GEM values), which could potentially indicate the influence of shipping routes on GEM measured at CPT GAW. Secondly, air masses that had passed over the very sparsely populated semi-arid Karoo region, almost directly to the north of CPT GAW, were mostly associated with cluster two (lower GEM values). The aforementioned differences in source regions for GEM did not seem to be associated with back trajectory heights, e.g. subsiding air masses from the free troposphere. It was found that the mean height of trajectories resulting in low and high GEM concentrations were almost identical, i.e. 1178 and $1104 \mathrm{~m}$, respectively. A slight difference was observed for the mean air mass back trajectory maximum height, with the lower and higher GEM concentrations peaking at $2785 \mathrm{~m}$ and $2654 \mathrm{~m}$, respectively. Similarly, the heights of trajectories passing over land (5 hours or more) were investigated. The mean heights of continental trajectories from cluster one (high GEM) and cluster two (low GEM) were 1490 and $1632 \mathrm{~m}$, and the mean maximum heights of continental trajectories were 3352 and $3599 \mathrm{~m}$, respectively.

The possibility of shipping routes contributing to the high GEM concentrations observed around the coast of South Africa was further investigated. From the Automated Mutual-Assistance Vessel Rescue System (AMVER) website, sponsored by the United States Coast Guard, Fig. 5 was obtained. In Fig. 5, the daily ship locations, derived from an average of 4634 ships per day, for July 2011 are presented in a density plot. The July 2011 timeframe was chosen since it was within the GEM data analysis period. The shipping route density plot indicated in Fig. 5 also closely correlates with $\mathrm{NO}_{x}$ shipping tracks characterised by satellite observations (Skjølsvik et al., 2000; Richter et al., 2011). The similarities of shipping route densities and $\mathrm{NO}_{x}$ shipping tracks, with the areas indicating additional contributions to higher GEM values (as indicated in Fig. 4c), provide credibility to the postulation that shipping around South Africa contributes meaningfully to GEM measured at CPT GAW.

Slemr et al. (2013) and Brunke et al. (2004) demonstrated how ${ }^{222} \mathrm{Rn}$ could be used to identify lower GEM concentrations that were associated with air masses passing over the marine background and higher GEM levels that were associated with a continental influence. In an effort to gain further insight into the difference between continental and marine background GEM concentrations at CPT GAW, the hourly arriving back trajectories calculated for the entire sampling period were divided into groups according to the time that (a)

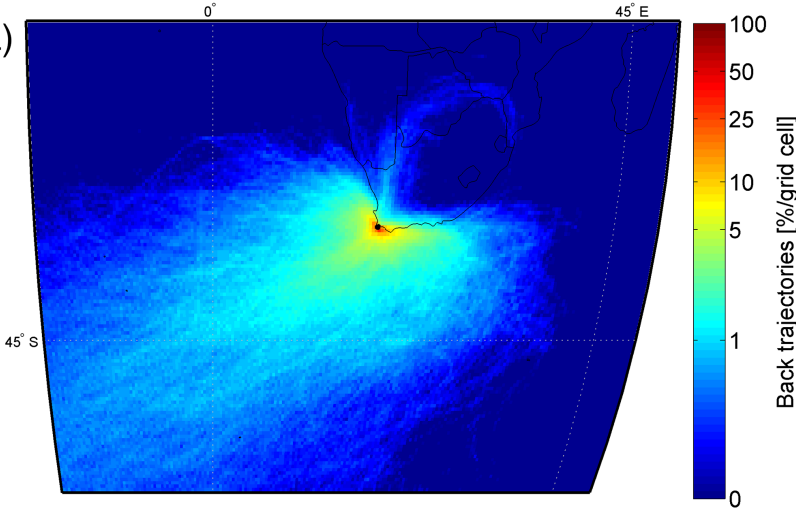

(b)

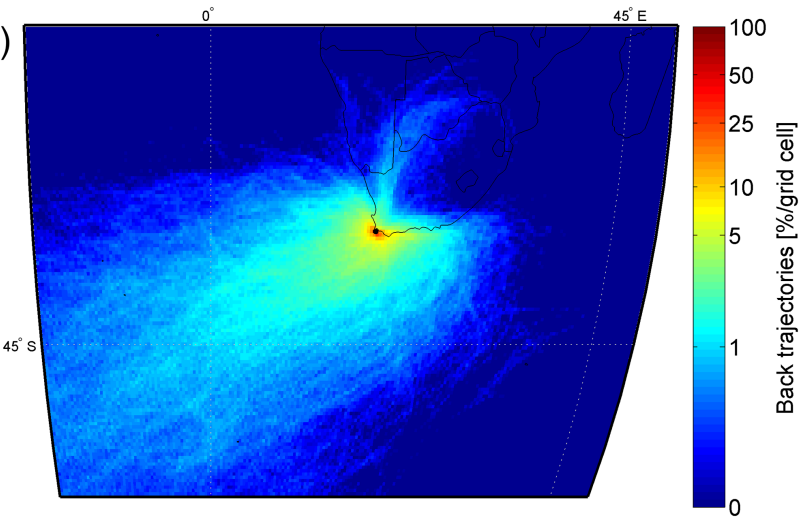

(c)

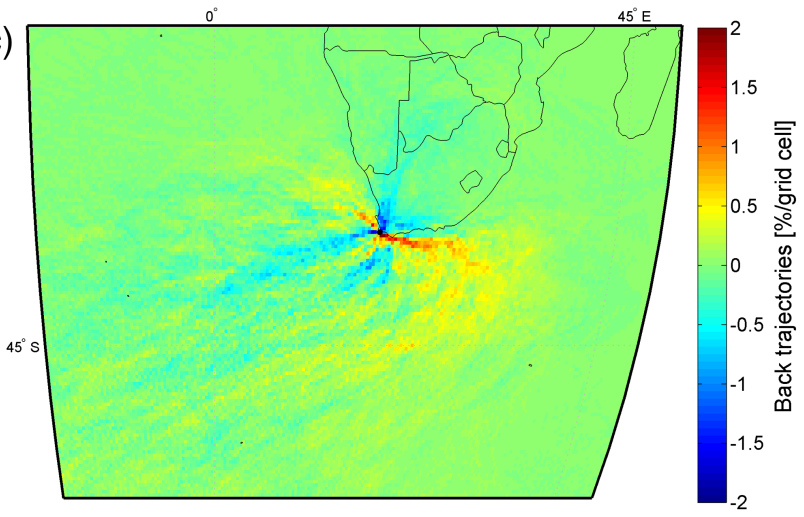

Figure 4. Normalised back trajectory analysis map, i.e. hourly arriving 8-day back trajectories with $100 \mathrm{~m}$ arrival height overlaid with MATLAB and normalised to percentage for the entire sampling period for, (a) cluster one, i.e. GEM concentration $>0.904 \mathrm{ng} \mathrm{m}^{-3}$, (b) for cluster two, i.e. GEM concentration $<0.904 \mathrm{ng} \mathrm{m}^{-3}$ and (c) the difference between the two individual maps, i.e. percentage of trajectories passing over each correlating $0.2^{\circ} \times 0.2^{\circ}$ grid cells in (b) subtracted from the percentage of trajectories passing over each $0.2^{\circ} \times 0.2^{\circ}$ grid cell in (a). The colour bar indicates the percentage of trajectories passing over each grid cell. 


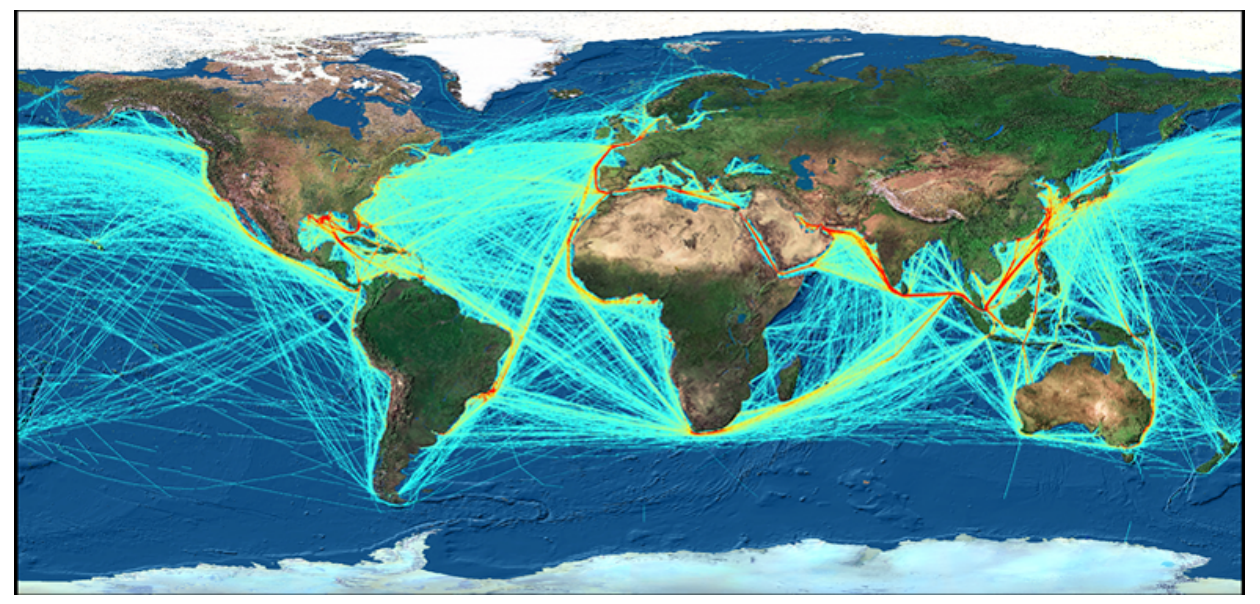

Figure 5. Monthly density plot for the total number of ships registered with Automated Mutual-Assistance Vessel Rescue System (AMVER) for July 2011. AMVER is sponsored by the United States Coast Guard and makes use of the global ship reporting system used worldwide by search and rescue authorities. The ship density plot is compiled from a 2011 average of 4634 ships per day (United States Coast Guard, 2014).

these air masses had spent over the African continent. The statistical distribution of GEM concentrations and the time that air masses spent over the continent are presented in Fig. 6a, while in Fig. $6 b^{222} \mathrm{Rn}$ distribution as a function of time air masses spent over the continent is shown.

An evident trend is observed in Fig. 6a, i.e. an increase of GEM concentrations for air masses that spent more time over the continent. As expected, back trajectories of air masses spending shorter times over the continent were on average associated with the lowest GEM concentrations. However, these groups also had the largest spread in GEM concentrations $\left( \pm 0.6 \mathrm{ng} \mathrm{m}^{-3}\right)$. This can at least partially be explained by uncertainties in the back trajectory calculations. During these calculations, a single hourly position of the air mass was determined for each of its 8-day backward positions. This relatively weak temporal resolution implies that an air mass could, for instance, have passed over the relatively nearby Cape Town conurbation, without being registered as spending any time over the continent. Additionally, the accuracy of trajectories depends on the quality of the underlying meteorological data used during the calculations. Considering the afore-mentioned limitations, the errors accompanying a single trajectory are currently estimated to be 15 to $30 \%$ of the trajectory distance travelled (Vakkari et al., 2013; Stohl, 1998; Riddle et al., 2006). It is therefore possible that a trajectory could have spent a short period over the continent, without being calculated as such. Notwithstanding the possible errors associated with the calculation of individual back trajectories, the large number of trajectories calculated in this study (24/day $\times 365$ days $\times \sim 5$ years $)$ ensures that the data obtained is statistically representative. The average marine background GEM concentration for the entire sampling period according to the ${ }^{222} \mathrm{Rn}$ level classification ( $<100 \mathrm{mBq} \mathrm{m}^{-3}-$ as proposed by Brunke et al., 2004) was
$0.89 \pm 0.106 \mathrm{ng} \mathrm{m}^{-3}$, while the average GEM level for air masses that spent 1 hour or less over the continent (Fig. 6a) was $0.92 \pm 0.300 \mathrm{ng} \mathrm{m}^{-3}$. This indicates that the classification of air masses arriving at the CPT GAW station with back trajectory analysis correlates well with air mass classification according to ${ }^{222} \mathrm{Rn}$ levels. However, the ${ }^{222} \mathrm{Rn}$ classification method only allows for the separation of the CPT GAW GEM data into relatively few classes, i.e. marine background, mixed and continentally influenced, while the back trajectory analysis methods provide a more quantified classification based on the length of time that air masses spent over the continent resulting in increased GEM concentrations. It is evident from comparison between Fig. $6 a$ and $b$ that back trajectory analysis provides a more sensitive method of characterising GEM according to time that air masses spent over the continent up to $11 \mathrm{~h}$ (where GEM concentrations reached a plateau), while ${ }^{222} \mathrm{Rn}$ classification only allows separation within 3 hours that air masses spent over the continent. The difference in average GEM concentrations between air masses that had spent 1 hour or less over the continent, i.e. $0.92 \mathrm{n} \mathrm{m}^{-3}$ and air masses that had spent more than 11 hours on the continent, i.e. $1.09 \pm 0.150 \mathrm{ng} \mathrm{m}^{-3}$, therefore provides some quantified indication of the possible continental contribution of GEM at CPT GAW. When GEM concentrations were classified according to ${ }^{222} \mathrm{Rn}$ levels, i.e. ${ }^{222} \mathrm{Rn}$ levels $>1000 \mathrm{mBq} \mathrm{m}^{-3}$ indicating continentally influenced air masses (Slemr et al., 2013), $50 \%$ of the data was greater than $0.92 \mathrm{ng} \mathrm{m}^{-3}$. This value is somewhat lower than the average concentration value determined for air masses spending more than $11 \mathrm{~h}$ over the continent, i.e. $1.09 \mathrm{ng} \mathrm{m}^{-3}$.

According to Jacob et al. (1997), the assumption of a uniform ${ }^{222} \mathrm{Rn}$ emission rate of 1 atom $\mathrm{cm}^{-2} \mathrm{~s}^{-1}$ is accurate to roughly $25 \%$ globally, or by a factor of 2 regionally. Therefore the 15-30\% error associated with back trajectory 


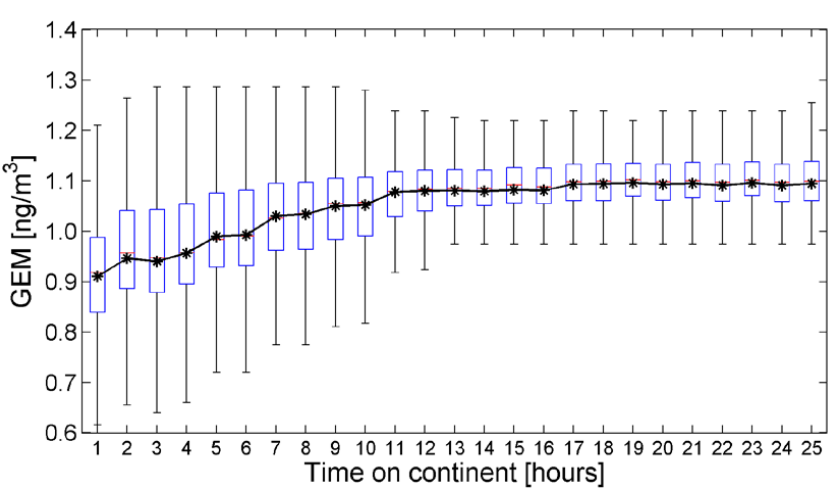

(a)

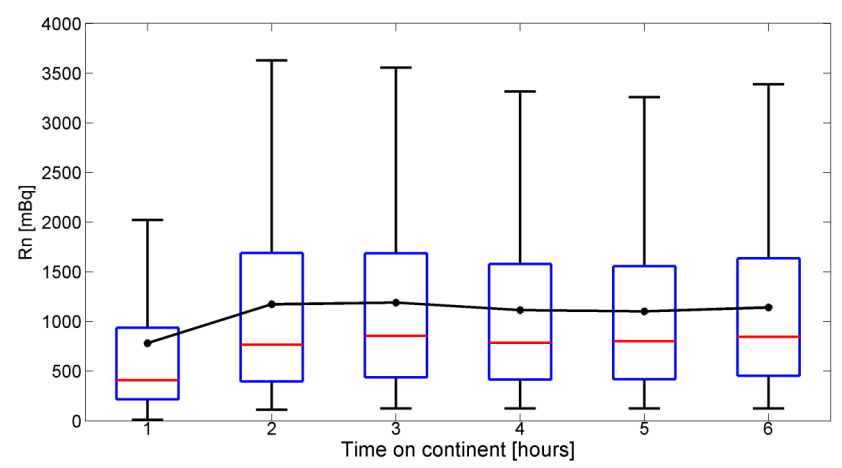

(b)

Figure 6. (a) The statistical distribution of GEM concentrations as a function of time spent over the continent and (b) ${ }^{222} \mathrm{Rn}$ distribution as a function time air masses spent over the continent. The mean is indicated by the black stars, the median by the red line, the 25 - and 50 percentile by the blue box and the whiskers indicating $99.3 \%$ data coverage (if a normal distribution is assumed), while the black line connects the mean values to provide an indication of the trend observed.

analysis is in the same range as the uncertainties associated with ${ }^{222} \mathrm{Rn}$ as tracer.

\subsection{Relationship of GEM with other parameters}

In an effort to determine relationships between atmospheric GEM concentrations and other atmospheric parameters measured at the CPT GAW station, as well as to establish whether GEM levels could be estimated or predicted from these parameters, multi-linear regression (MLR) analysis was conducted. In Fig. 7, the RMSE difference between the calculated and measured GEM values, as a function of the number of independent variables included in the optimum MLR solution, is presented. The linear equation containing only a single optimum independent variable, which was determined as absolute humidity, had an RMSE of $\sim 0.1250$, while the RMSE was lowered to $\sim 0.1231$ if an MLR equation containing the optimum combination of two independent variables, i.e. absolute humidity and $\mathrm{O}_{3}$, was calculated. The RMSE

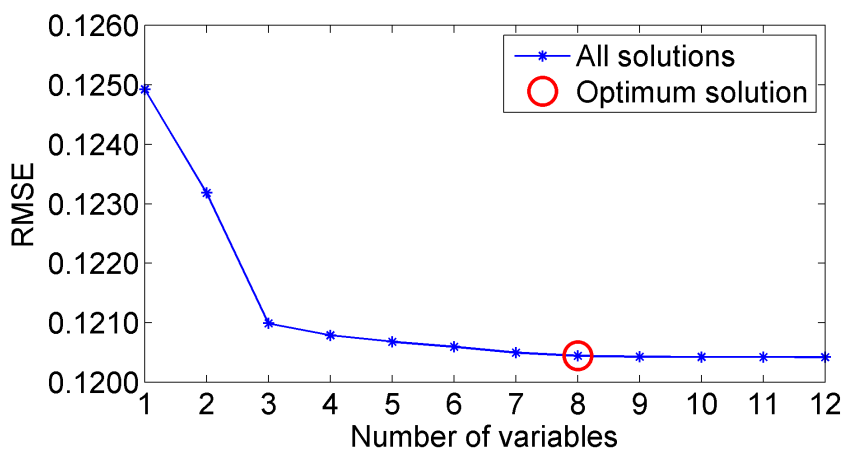

Figure 7. Determination of the optimum combination of independent variables to include in the MLR equation to calculate the dependant variable, i.e. GEM concentration (2007-2011). The root mean square error (RMSE) difference between the calculated and actual GEM concentrations indicated that the inclusion of eight parameters in the MLR solution was the optimum.

Table 2. The overall identity of independent variables during the determination of the optimum combination of independent variables for GEM calculation utilising the entire data set.

\begin{tabular}{ccccccccc}
\hline $\begin{array}{c}\text { No of } \\
\text { independent } \\
\text { variables }\end{array}$ & & & & & & & \\
& & & & \\
& & & & \\
1 & $\mathrm{AbsH}$ & & & & & & & \\
2 & $\mathrm{AbsH}$ & $\mathrm{O}_{3}$ & & & & & & \\
3 & $\mathrm{AbsH}$ & $\mathrm{O}_{3}$ & $\mathrm{CO}$ & & & & & \\
4 & $\mathrm{AbsH}$ & $\mathrm{O}_{3}$ & $\mathrm{CO}$ & $P$ & & & & \\
5 & $\mathrm{AbsH}$ & $\mathrm{O}_{3}$ & $\mathrm{CO}$ & $P$ & $T$ & & & \\
6 & $\mathrm{AbsH}$ & $\mathrm{O}_{3}$ & $\mathrm{CO}$ & $P$ & $T$ & $\mathrm{CH}_{4}$ & & \\
7 & $\mathrm{AbsH}$ & $\mathrm{O}_{3}$ & $\mathrm{CO}$ & $P$ & $T$ & $\mathrm{CH}_{4}$ & $\mathrm{Rn}$ & \\
8 & $\mathrm{AbsH}$ & $\mathrm{O}_{3}$ & $\mathrm{CO}$ & $P$ & $T$ & $\mathrm{CH}_{4}$ & $\mathrm{Rn}$ & WGS \\
\hline
\end{tabular}

difference between the experimental and calculated GEM values could further be reduced if the optimum MLR solution contained more independent variables. The optimised RMSE was attained when the number of independent variables included in the optimum solution of the equation was increased to eight, and had an RMSE of 0.1205 . The measure of optimisation was taken as at least $1 \%$ contribution to the overall reduction of RMSE. Table 2 indicates the identity of the independent parameters determined for each of the optimum MLR solutions.

The inclusion of more independent variables in the MLR solution did not significantly reduce the RMSE, and this can be seen in Fig. 7. A new MLR equation was determined with every addition of independent variables to determine the optimum variable combinations. This implies that new constants were calculated for all independent variables in each new optimum variable combination. Therefore, the afore-mentioned reductions in RMSE observed with an increase in the number of independent variables included in the optimum solution was an overall reduction of RMSE resulting from the increased number of independent variables included in the 
combination and not due to the contribution of a single (or two) independent variable(s). The identity and constants associated with the independent variables in the identified optimum MLR solution to predict GEM, i.e. the dependant variable, are provided in Eq. (1):

$$
\begin{aligned}
\mathrm{GEM}= & -1.2308+1.492 \times 10^{-3} \mathrm{AbsH}-3.790 \times 10^{-3} \\
& \mathrm{O}_{3}+6.220 \times 10^{-4} \mathrm{CO}+1.3630 \times 10^{-3} \mathrm{P} \\
& +6.280 \times 10^{-3} \mathrm{~T}+2.180 \times 10^{-4} \\
& \mathrm{CH}_{4}-5.530 \times 10^{-6} \mathrm{Rn}-1.110 \times 10^{-3} \mathrm{WGS}
\end{aligned}
$$

with GEM in $\mathrm{ng} \mathrm{m}^{-3}$, gaseous species $\left(\mathrm{CO}, \mathrm{CH}_{4}, \mathrm{O}_{3}\right.$ and $\mathrm{CO}_{2}$ ) in ppb, $T$ in ${ }^{\circ} \mathrm{C}$, WGS indicating wind gust speed in $\mathrm{km} \mathrm{h}^{-1}, \mathrm{AbsH}$ the absolute humidity in $\mathrm{g} \mathrm{m}^{-3}$ and $P$ the ambient pressure in hectopascal (hPa). In Eq. (1), independent variables associated with positive constants indicate that an increase in these parameters would statistically lead to an increase in atmospheric GEM, whereas the increase in independent variables associated with negative constants would statistically lead to lower GEM. Although the MLR equations cannot be used to explicitly derive the origin and/or reaction mechanistic information about GEM at CPT GAW, it could be used to provide some insight.

The positive constants associated with $\mathrm{CO}$ and $\mathrm{CH}_{4}$ could indicate that higher GEM can be attributed to anthropogenic emissions such as fossil fuel (e.g. shipping) and household combustion, as well as natural biomass burning observed during pollution events (Brunke et al., 2010a). Higher $\mathrm{O}_{3}$ leads to higher hydroxyl $(\cdot \mathrm{OH})$ radical concentrations, therefore the possible negative constant associated with $\mathrm{O}_{3}$. As discussed in Lan et al. (2012) and the references therein, GEM may be oxidised by $\cdot \mathrm{OH}$, nitrate $\left(\mathrm{NO}_{3} \cdot{ }^{\circ}\right)$ or halogen $(\mathrm{X} \cdot)$ radicals. Gierens et al. (2014) recently indicated that - $\mathrm{OH}$ concentrations reach a peak around midday in the interior of SA, and since $\cdot \mathrm{OH}$ has a lifetime of $\sim 1 \mathrm{~s}$, its diurnal variation will therefore follow the diurnal variation of the UV radiation with wavelength capable to photolyse $\mathrm{O}_{3}$ to $\mathrm{O}^{1} \mathrm{D}$, and therefore achieving peak GEM oxidation during midday. Additionally, the negative constant associated with $\mathrm{O}_{3}$ in Eq. (2) could also indicate aged air masses, in which GEM decreased (e.g. by oxidation and deposition). The photochemically driven oxidation of GEM results in the formation of gaseous oxidised mercury (GOM). Particulate bound mercury (PBM) and GOM typically reach diurnal minima before sunrise and maxima in the afternoon (Lan et al., 2012). It has been suggested that an abundant halogen radical $(\mathrm{X} \cdot)$ concentration present in the marine environment may lead to higher GOM concentrations (Mao and Talbot, 2012). The photochemically driven oxidation of GEM to GOM in summer depletes GEM levels during midday when solar radiation, $\mathrm{O}_{3}$ levels and atmospheric halogens produced by sea spray are the most intense and would therefore explain negative constants in Eq. (1). This signifies the com-
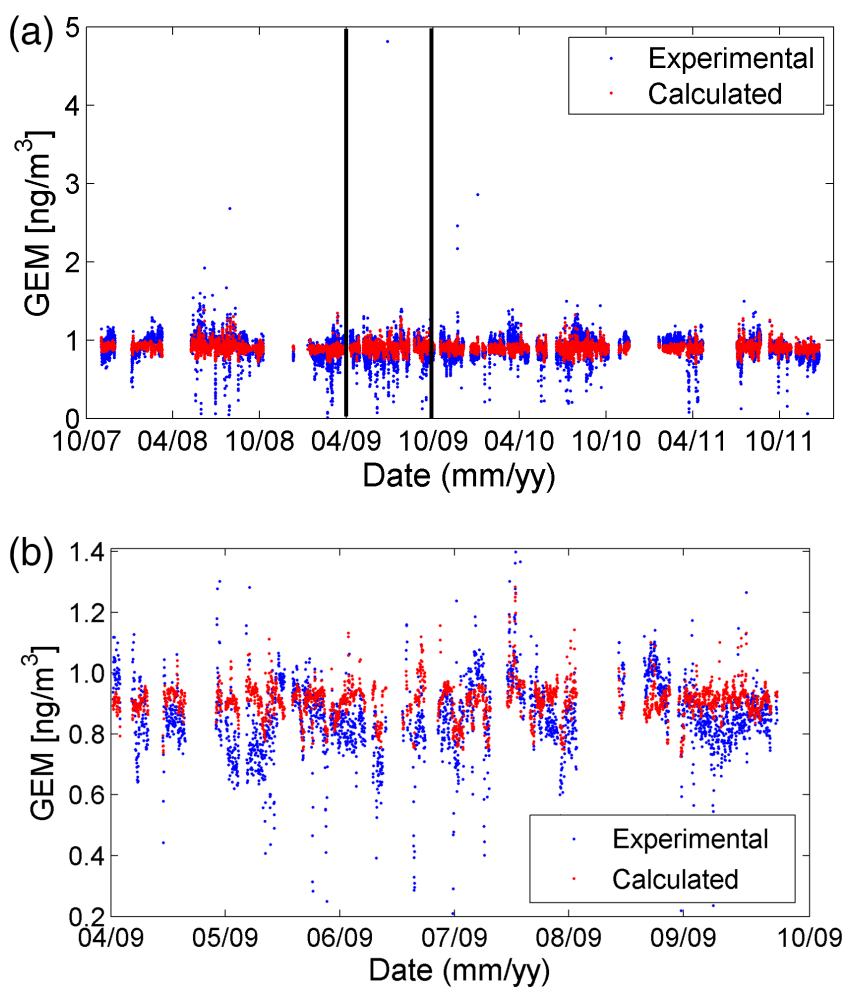

Figure 8. (a) Measured GEM (blue) and calculated GEM concentrations using the MLR Eq. (1) (red) for the entire sampling period. The two vertical black lines in (a) indicate a period that was enlarged in (b) to indicate more detailed differences between the measured and calculated GEM concentrations.

plex nature of the interaction between chemical species and the physical environment in the atmosphere.

In addition to providing some insight into the origin and/or reactions of GEM at CPT GAW, it would also be useful to predict GEM at this site with the MLR Eq. (1). In Fig. 8, the measured time series for atmospheric GEM at CPT GAW are presented (blue markers) and compared to the GEM values calculated with Eq. (1) (red markers). Although slight differences are observed, the MLR equation predicts atmospheric GEM concentrations relatively well, with the exception of very high and low levels. Therefore, the MLR Eq. (1) could be used to predict GEM concentrations at CPT GAW if actual measurements thereof are not available.

Although not indicated in Fig. 8 (to prevent cluttering of the graph), linear fitting of the actual continuous measured and calculated (with Eq. 1) GEM concentrations indicated negative slopes of $-5.579 \times 10^{-6}$ and $-1.391 \times 10^{-5}$, respectively. This indicates a slight decrease of GEM concentrations at CPT GAW over the evaluated period. Brunke et al. (2010a) previously also reported a decrease in GEM at CPT GAW from 1995 to 2009, but this reported decline only included approximately 2 years of continuous measurement. The decline observed for the longer time series reported here provides additional support to the observed decline. In con- 
trast, Slemr et al. (2015) reported an increase in GEM concentration at CPT GAW. However, this increase was calculated by utilising pre-processed, i.e. de-trended and deseasonalised data, which was not the case in this study. Therefore these different approaches cannot be directly compared.

\section{Conclusions}

As far as the authors could assess, this is the first study that has evaluated continuous high-resolution GEM data of CPT GAW with different statistical analysis techniques. Cluster analysis on the data set indicated that the GEM data could be divided into two clusters, separated at atmospheric concentrations of $0.904 \mathrm{ng} \mathrm{m}^{3}$. Trajectory analyses of the individual clusters, as well as the differences between these clusters, indicated that shipping around Cape Point could be a significant source of GEM. In contrast, low GEM concentrations originated from the southern oceanic background and terrestrial areas with very low anthropogenic activities/population density. Correlation of the time that back trajectories spent over the African continent and GEM concentration, proved that such analyses could be used as an alternative tool to distinguish between continental and marine GEM contributions.

It was also demonstrated that MLR analysis could be used to determine an equation that can be used to predict GEM at CPT GAW. Moreover, this equation provided some insight into the complex nature of GEM chemistry. Lastly, the evaluation of both continuously measured and calculated (with the determined MLR Eq. 1) GEM concentrations seem to indicate a decline in GEM concentrations over the period evaluated in this paper. It remains to be seen whether this decline continues, which would reflect a positive response to global $\mathrm{Hg}$ emission reductions, or if it is only part of a longer-term cycle with a temporary decline.

From this statistical study of continuous GEM measurement at Cape Point additional research questions and/or perspectives were identified. Data indicated as extreme events, as indicated by 5, 6 and 7 cluster solutions should be investigated as special case studies. Further research quantifying the contribution of shipping should be undertaken, not only for the southern African region, but also for other busy shipping routes. In addition, source apportionment should be conducted in order quantify the contribution of specific sources.

Acknowledgements. The authors would like to thank the South African Weather Service for making available the GEM data measured at CPT GAW. The financial assistance of the National Research Foundation (NRF) towards this research is hereby acknowledged. Opinions expressed and conclusions arrived at are those of the authors and are not necessarily to be attributed to the NRF.

Edited by: C. Barbante

\section{References}

Angot, H., Barret, M., Magand, O., Ramonet, M., and Dommergue, A.: A 2-year record of atmospheric mercury species at a background Southern Hemisphere station on Amsterdam Island, Atmos. Chem. Phys., 14, 11461-11473, doi:10.5194/acp14-11461-2014, 2014.

Baker, P. G. L., Brunke, E.-G., Slemr, F., and Crouch, A. M.: Atmospheric mercury measurements at Cape Point, South Africa, Atmos. Environ., 36, 2459-2465, 2002.

Brunke, E.-G., Scheel, H. E., and Seiler, W.: Trends of tropospheric $\mathrm{CO}, \mathrm{N}_{2} \mathrm{O}$ and $\mathrm{CH}_{4}$ as observed at Cape Point, South Africa, Atmos. Environ., 24A, 585-595, 1990.

Brunke, E.-G., Labuschagne, C., Parker, B., Scheel, H. E., and Whittlestone, S.: Baseline airmass selection at Cape Point, South Africa: application of ${ }^{222} \mathrm{Rn}$ and other filter criteria to $\mathrm{CO}_{2}$, Atmos. Environ., 38, 5693-5702, doi:10.1016/j.atmosenv.2004.04.024, 2004.

Brunke, E.-G., Slemr, F., Ebinghaus, R., and Kock, H.: Atmospheric Mercury Measurements at Cape Point, South Africa, Clean Air J., 18, 17-21, 2010a.

Brunke, E.-G., Labuschagne, C., Ebinghaus, R., Kock, H. H., and Slemr, F.: Gaseous elemental mercury depletion events observed at Cape Point during 2007-2008, Atmos. Chem. Phys., 10, 11211131, doi:10.5194/acp-10-1121-2010, 2010 b.

Ebinghaus, R., Jennings, S. G., Schroeder, W. H., Berg, T., Donaghy, T., Guentzel, J., Kenny, C., Kock, H. H., Kvietkus, K., Landing, W., Muhleck, T., Munthe, J., Prestbo, E. M., Schneeberger, D., Slemr, F., Sommar, J., Urba, A., Wallschlager, D., and Xiao, Z.: International field intercomparison measurements of atmospheric mercury species at Mace Head, Ireland, Atmos. Environ., 33, 3063-3073, 1999.

Ebinghaus, R., Kock, H. H., Temme, C., Einax, J. W., Lowe, A. G., Richter, A., Burrows, J. P., and Schroeder, W. H.: Antarctic springtime depletion of atmospheric mercury, Environ. Sci. Technol., 36, 1238-1244, 2002.

Gierens, R. T., Laakso, L., Mogensen, D., Vakkari, V., Beukes, J. P., Van Zyl, P. G., Hakola, H., Guenther, A., Pienaar, J. J., and Boy, M.: Modelling new particle formation events in the South African savannah, S. Afr. J. Sci., 110, 2013-0108, doi:10.1590/sajs.2014/20130108, 2014.

Jacob, D. J., Prather, M. J., Rasch, P. J., Shia, R.-L., Balkanski, Y. J., Beagley, S. R., Bergmann, D. J., Blackshear, W. T., Brown, M., Chiba, M., Chipperfield, M. P., de Grandpáe, J., Dignon, J. E., Feichter, J., Genthon, Ch., Grose, W. L., Kasibhatla, P. S., Kohler, I., Kritz, M. A., Law, K., Penner, J. E., Ramonet, M., Reeves, C. E., Rotman, D. A., Stockwell, D. Z., van Velthoven, P. F. J., Verver, G., Wild, O., Yang, H., and Zimmermann, P.: Evaluation and intercomparison of global atmospheric transport models using 222Rn and other short-lived tracers, J. Geophys. Res., 102, 5953-5970, 1997.

Lan, X., Talbot, R., Castro, M., Perry, K., and Luke, W.: Seasonal and diurnal variations of atmospheric mercury across the US determined from AMNet monitoring data, Atmos. Chem. Phys., 12, 10569-10582, doi:10.5194/acp-12-10569-2012, 2012.

Laudal, D. L., Pavlish, J. H., Graves, J., and Stockdill, D.: Mercury mass balances: A case study of two North Dakota Power Plants, J. Air Waste Manage. Assoc., 50, 1798-1804, 2000.

Lin, C.-J., Pongprueksa, P., Lindberg, S. E., Pehkonen, S. O., Byun, D., and Jang, C.: Scientific uncertainties in atmospheric mercury 
models I: Model science evaluation, Atmos. Environ., 40, 29112928, 2006.

Lindberg, S., Bullock, R., Ebinghaus, R., Engstrom, D., Feng, X., Fitzgerald, W., Pirrone, N., Prestbo, E., and Seigneur, C.: A synthesis of progress and uncertainties in attributing the sources of mercury in deposition, Ambio, 36, 19-32, 2007.

Lourens, A. S. M., Beukes, J. P., van Zyl, P. G., Fourie, G. D., Burger, J. W., Pienaar, J. J., Read, C. E., and Jordaan, J. H.: Spatial and Temporal assessment of Gaseous Pollutants in the Mpumalanga Highveld of South Africa, S. Afr. J. Sci., 107, 269, doi:10.4102/sajs.v107i1/2.269, 2011.

Lourens, A. S. M., Butler, T. M., Beukes, J. P., van Zyl, P. G., Beirle, S., and Wagner, T.: Re-evaluating the $\mathrm{NO}_{2}$ hotspot over the South African Highveld, S. Afr. J. Sci., 108, 1146, doi:10.4102/sajs.v108i11/12.1146, 2012.

Mao, H. and Talbot, R.: Speciated mercury at marine, coastal, and inland sites in New England - Part 1: Temporal variability, Atmos. Chem. Phys., 12, 5099-5112, doi:10.5194/acp-12-50992012, 2012.

Mason, R. P.: Mercury emissions from natural processes and their importance in the global mercury cycle, Springer, New York, USA, 2009.

Mergler, D., Anderson, H. A., Chan, L. H. M., Mahaffey, K. R., Murray, M., Sakamoto, M., and Stern, A. H.: Methylmercury exposure and health effects in humans: A worldwide concern, Ambio, 36, 3-11, 2007.

Pirrone, N., Cinnirella, S., Feng, X., Finkelman, R. B., Friedli, H. R., Leaner, J., Mason, R., Mukherjee, A. B., Stracher, G. B., Streets, D. G., and Telmer, K.: Global mercury emissions to the atmosphere from anthropogenic and natural sources, Atmos. Chem. Phys., 10, 5951-5964, doi:10.5194/acp-10-59512010, 2010.

Richter, A., Begoin, M., Hilboll, A., and Burrows, J. P.: An improved $\mathrm{NO}_{2}$ retrieval for the GOME-2 satellite instrument, Atmos. Meas. Tech., 4, 1147-1159, doi:10.5194/amt-4-1147-2011, 2011.

Riddle, E. E., Voss, P. B., Stohl, A., Holcomb, D., Maczka, D., Washburn, K., and Talbot, R. W.: Trajectory model validation using newly developed altitude-controlled balloons during the International Consortium for Atmospheric Research on Transport and Transformations 2004 campaign, J. Geophys. Res., 111, D23S57, doi:10.1029/2006JD007456, 2006.
Scott, G. M. and Mdluli, T. N.: The Minamata Treaty/Protocol: Potential Implications for South Africa, Clean Air J., 22, 17-19, 2012.

Skjølsvik, K. O., Andersen, A. B., Corbett, J. J., and Skjelvik, J. M.: Study of Greenhouse Gas Emissions from Ships, 2nd Edn., Norwegian Marine Technology Research Institute, Trondheim, 2000.

Slemr, F., Brunke, E.-G., Labuschagne, C., and Ebinghaus, R.: Total gaseous mercury concentrations at the Cape Point GAW station and their seasonality, Geophys. Res. Lett., 35, L11807, doi:10.1029/2008GL033741, 2008.

Slemr, F., Brunke, E.-G., Ebinghaus, R., and Kuss, J.: Worldwide trend of atmospheric mercury since 1995, Atmos. Chem. Phys., 11, 4779-4787, doi:10.5194/acp-11-4779-2011, 2011.

Slemr, F., Brunke, E.-G., Whittlestone, S., Zahorowski, W., Ebinghaus, R., Kock, H. H., and Labuschagne, C.: ${ }^{222}$ Rn-calibrated mercury fluxes from terrestrial surface of southern Africa, Atmos. Chem. Phys., 13, 6421-6428, doi:10.5194/acp-13-64212013, 2013.

Slemr, F., Angot, H., Dommergue, A., Magand, O., Barret, M. Weigelt, A., Ebinghaus, R., Brunke, E.-G., Pfaffhuber, K. A., Edwards, G., Howard, D., Powell, J., Keywood, M., and Wang, F.: Comparison of mercury concentrations measured at several sites in the Southern Hemisphere, Atmos. Chem. Phys., 15, 3125 3133, doi:10.5194/acp-15-3125-2015, 2015.

Stohl, A.: Computation, accuracy and application of trajectories - a review and bibliography, Atmos. Environ., 32, 947-966, 1998.

United States Coast Guard: AMVER, available at: http://www. amver.com/, last access: 17 November 2014.

Vakkari, V., Beukes, J. P., Laakso, H., Mabaso, D., Pienaar, J. J., Kulmala, M., and Laakso, L.: Long-term observations of aerosol size distributions in semi-clean and polluted savannah in South Africa, Atmos. Chem. Phys., 13, 1751-1770, doi:10.5194/acp13-1751-2013, 2013.

Venter, A. D., Vakkari, V., Beukes, J. P., van Zyl, P. G., Laakso, H., Mabaso, D., Tiitta, P., Josipovic, M., Kulmala, M., Pienaar, J. J., and Laakso, L.: An air quality assessment in the industrialized western Bushveld Igneous Complex, South Africa, S. Afr. J. Sci., 108, 1059, doi:10.4102/sajs.v108i9/10.1059, 2012.

Wagner, N. J.: Trace Elements in coal, their analysis and environmental impact, Literature Survey, SASOL R\&D, Sasolburg, 2001. 